rheumatic fevers; two mitral stenotics in failure (with mitral incompetence); one mitral stenotic just cardioverted from atrial fibrillation; one mitral stenotic post-valvotomy; one aortic incompetence with pneumonia; numerous coronaries; two pneumococcal meningitis; two meningococcal meningitis; typhoid; systemic lupus erythematosus; sarcoid; scleroderma; two rheumatoids; bleeding duodenal ulcer; postoesophageal transection; cirrhotic with ascites; idiopathic thrombocytopenic pupura; hepatoma; carcinoma of the stomach; myxoedema; hydatid cyst in lung; numerous asthmatics; numerous bronchiectatics; numerous diabetics for control; one polyneuritis; subarachnoid haemorrhage; hirsutes for investigation; and others I cannot remember-I have over 60 patients under my care at present looked after by me and three registrars.

The work load in Kuwait city would be similar but more use is made there of specialist departments. Our biggest problems are getting drugs registered in Kuwait so that we may obtain them. It can be a source of inconvenience but, frankly, I don't find it any more frustrating than the NHS. Maintaining equipment is really a major problem, because good technical people are scarce-everyone seems to be a boss or a labourer, a familiar problem.

Finally, I must mention that women can work, drive, and wander freely in Kuwait-it is one of the least restrictive areas of the Middle East, although the freedom of the West is still a little distant.

\title{
How to do it
}

\section{Use a library}

\author{
MORAG C TIMBURY
}

British Medical fournal, 1979, 1, 252-253

"A library is thought in cold storage"

\section{Lord Samuel}

Most doctors use a library, either regularly or occasionally. Many, like myself, probably do so without encountering any particular problems but without realising the full range of services available in large libraries.

Britain is fortunate in being well endowed with excellent and comprehensive medical libraries. Although London has more libraries than anywhere else, first-class facilities are available throughout Britain-for example, in universities with medical schools, royal colleges, research institutions, and postgraduate teaching centres. Doctors who live some distance from a major library may use the excellent BMA library, which runs a postal service for both books and periodicals.

\section{Departmental and main libraries}

Most hospital units maintain small departmental libraries which stock books and periodicals of particular interest to each department. These libraries are expensive because they buy many of the same journals and books already available in a main library or neighbouring departments, but they are nevertheless indispensable for keeping up to date with one's own subject. Most doctors can find some free time during working hours for a browse through current issues. Departmental libraries usually subscribe to journals of general medical interest such as the BMF, Lancet, and Nature. Some 20 years ago Sir James Howie recommended the editorials of these three journals to me as a sure way of keeping up with the major developments in medicine

Institute of Virology, University of Glasgow, Church Street, Glasgow G11 5JR

MORAG C TIMBURY, MD, FRCPATH, reader in virology

-excellent advice, even if I have not always followed it as diligently as I should have done. Many departmental libraries take Current Contents-a weekly publication that lists photocopies of the contents pages of a large number of biomedical journals. My worst mistake as a departmental librarian was to allow myself to be persuaded to cancel this subscription on financial grounds-a good example of false economy. Half-an-hour each week with Current Contents and a pile of reprint request cards is a rewarding exercise. The numerous abstract journals that are available in various specialties also have a useful part to play, but tend to be rather slow in fastdeveloping fields.

No departmental library can be comprehensive and most doctors will need to use a large library as well, such as a university library. These main (as distinct from departmental) libraries hold many periodicals and books; moreover, any book or journal not available locally can normally be obtained from the British Library Lending Division at Boston Spa in Yorkshire. Nowadays, articles from periodicals held in Boston Spa are supplied as photocopies within a few days of request.

\section{Catalogues and searches}

It may seem obvious, but is worth emphasising, that readers can save themselves a great deal of time by learning the system of catalogues in their local main library. An hourstudying the methods used and the layout of the library will be well spent, and will certainly save considerable time and frustration in the future. Library staff are always happy to help and their help in drawing attention to the available resources of the library is invaluable. It is also a good idea to become familiar with the various bibliographies that relate to publications available on one's own subject. A useful bibliography which is not so well known as its stable-mate, Index Medicus, is the National Library of Medicine Current Catalog, which lists textbooks, monographs, and conference proceedings rather than articles in periodicals.

Most medical readers will be familiar with Index Medicus. This comprehensive and invaluable publication appears monthly and lists articles in periodicals under the headings of subject and author, with a list of medical review articles at the 
front of each issue. A cumulative volume is published annually. Index Medicus has now been computerised as Medline, which is "on-line" at main libraries, and through which the reader may communicate direct with the computer. A typical search is based on a Medical Subject Heading (known as MESH) taken from the list in Index Medicus. Normally, the search would then be qualified by the inclusion of subheadings-for example, "aetiology" or "therapy"-so that the final print-out of references is reduced to manageable proportions. Medline is an incredibly fast and efficient way of obtaining a list of articles published on a given topic. A basic search on Medline normally covers publications from 1976, but can be extended back to 1966.

Doctors will want to use large libraries to read textbooks that are too expensive or too peripheral to their main interest to justify purchase. Another category of books of interest to medical readers are the various reference books. Who's Who, The Medical Register, and The Medical Directory are well known, but doctors may not be aware of the excellent The Hospitals and Health Services Year Book published by the Institute of Health Service Administrators. This book contains a wealth of information about hospitals in Britain including details of beds, administration, committees, and even a directory of hospital suppliers.

A key factor in using a large library successfully and efficiently is getting to know the staff. Most libraries are proud of their good staff, and professional help and advice from librarians can expedite difficult or urgent requests.

\section{How not to use a library}

Unfortunately, no article of this sort can ignore the negative side of library use. Librarians are well aware that otherwise honest and upright citizens occasionally show no apparent qualms of conscience about "removing" books. Unbound periodicals are particularly vulnerable, and this form of abuse causes an inordinate amount of trouble and delay when the time for binding arrives. Even more heinous, is the habit of tearing out a favourite or key article. The increasing availability of photocopying services might have been expected to diminish these deplorable habits but has not apparently done so.

A word of caution about photocopying should also be mentioned. Next to the speed limit, the copyright law is probably the law most often broken. Many readers may not realise that only one copy may be made of an article, and that one reader may copy only a single article from an issue of a periodical.

\section{Conclusion}

Of necessity, this article has presented my own personal way of using a library and I have certainly omitted mention of many other useful library services and facilities. Libraries have adapted to and have themselves adopted modern technological methods and offer a more rapid and comprehensive service than ever before. Now that communication is becoming increasingly important in clinical and research work, doctors can only gain from learning to make the best use of their local libraries.

I thank Mr R O McKenna, librarian, and Miss Sheila E Best, assistant librarian, of Glasgow University Library, for helpful advice and discussion.

\section{Suggested further reading}

Use of Medical Literature, ed L T Morton, 2nd edn. London, Butterworths, 1977.

Eventually this series will be collected into a book and hence no reprints will be available from the authors.

\title{
Aspects of Australian Medicine
}

\section{The Queensland Melanoma Project-an exercise in health education}

\author{
TONY SMITH
}

British Medical fournal, 1979, 1, 253-254

Among the malignant tumours melanoma has an especially sinister reputation: its insidious onset, often in someone in early adult life, is combined with a predilection for metastasis. In most reported series the mortality rate has been depressingly high, with five-year survival rates of $40^{\circ} \%$ or worse..$^{1-3}$ Melanoma seems to be most common in white-skinned persons regularly exposed to strong sunshine, so not surprisingly the highest incidence in the world is in Queensland, Australia's "sunshine state." What is surprising to a European visitor is that the

British Medical Journal

TONY SMITH, BM, BCH, deputy editor mortality from melanoma in Queensland is remarkably low. The age-adjusted cumulative five-year survival rate for women is $88 \%$, and for men it is $74 \%$. These impressive results are not due to any local variation in the malignancy of the disease: they are attributable to a sustained programme of health education that has made Queenslanders more melanoma-conscious than any comparable population in the world.

\section{Incidence of melanoma}

The data on melanoma in Queensland are probably unique; for a research study that was started there in 1963 has kept track of all patients in the state-public, private, city, and country-found to have primary melanoma. All patients treated anywhere in Queensland between 1963 and 1969 have been followed up; since 1970 the detailed follow-up has been con- 